\title{
Cara Tanam dan Pemupukan Tanaman Kacang Hijau di Lahan Kering Iklim Kering Sumba Timur, Nusa Tenggara Timur
}

\section{(Effect of Cropping Method and Fertilization to Mungbean in Dry Land in Dry Climate of East Sumba, East Nusa Tenggara)}

\author{
Sri Ayu Dwi Lestari*, Sutrisno, Henny Kuntyastuti
}

(Diterima Januari 2021/Disetujui Juni 2021)

\begin{abstract}
ABSTRAK
Cara tanam tumpang sari merupakan salah satu cara memaksimumkan pemanfaatan dan produktivitas tanaman dan tanah di lahan kering. Penelitian ini bertujuan mendapatkan teknik budi daya (cara tanam dan pemupukan) yang dapat meningkatkan hasil kacang hijau di lahan kering iklim kering (LKIK). Penelitian dilaksanakan di LIKIK di Desa Laipori, Kecamatan Pandawai, Kabupaten Sumba Timur, Nusa Tenggara Timur tahun 2017. Percobaan menggunakan rancangan split plot dengan empat ulangan. Petak utama adalah pola tanam, yaitu (1) kacang hijau tumpang sari jagung. Jarak tanam kacang hijau $30 \mathrm{~cm} \times 20 \mathrm{~cm}$, dua tanaman/lubang dan jarak tanam jagung $(50 \mathrm{~cm} \times 50 \mathrm{~cm}) \times 120$ $\mathrm{cm}$, satu tanaman/lubang dan (2) kacang hijau monokultur dengan jarak tanam $40 \mathrm{~cm} \times 10 \mathrm{~cm}$, dua tanaman/lubang. Anak petak adalah takaran dan jenis pupuk, yaitu (1) $150 \mathrm{~kg}$ Phonska/ha, (2) $5000 \mathrm{~kg}$ pupuk kandang/ha, dan (3) 75 $\mathrm{kg}$ Phonska $+2500 \mathrm{~kg}$ pupuk kandang/ha. Varietas kacang hijau yang digunakan ialah Vima 1 dan varietas jagung Bima. Hasil penelitian menunjukkan bahwa tumpang sari kacang hijau dengan jagung dapat meningkatkan hasil kacang hijau $0,28 \mathrm{t} / \mathrm{ha}(51,85 \%)$ dan meningkatkan biomassa panen kacang hijau $0,31 \mathrm{t} / \mathrm{ha}(22,30 \%)$ dibandingkan cara tanam monokultur. Perbedaan jenis dan takaran pupuk anorganik Phonska dan pupuk kandang tidak menyebabkan perbedaan hasil kacang hijau.
\end{abstract}

Kata kunci: jagung, kacang hijau, monokultur, tumpang sari, lahan kering

\section{ABSTRACT}

The intercropping method is one way to maximize plants and soil's utilization in a dry land. This study aimed to determine the cultivation (cropping methods and fertilization) that could increase mungbean grain yield in dry land in the dry climate of East Sumba, East Nusa Tenggara Province. The experiment was conducted at dry land in a dry climate in Laipori Village, Pandawai District, East Sumba Regency in 2017. The experiment was laid out in a split-plot design with four replications. The main plot was a cropping pattern, namely (1) intercropping mungbean with maize. Mungbean plant spacing was $30 \mathrm{~cm} \times 20 \mathrm{~cm}$, two plants per hole, and maize plant spacing was $(50 \mathrm{~cm} \times 50 \mathrm{~cm}) \times 120$ $\mathrm{cm}$, one plant/hole and (2) mungbean monoculture with a plant spacing of $40 \mathrm{~cm} \times 10 \mathrm{~cm}$, two plants/hole. The subplot was dosage and type of fertilizer, namely (1) $150 \mathrm{~kg}$ Phonska/ha, (2) $5000 \mathrm{~kg}$ cow manure/ha, and (3) $75 \mathrm{~kg}$ Phonska $+2500 \mathrm{~kg}$ cow manure/ha. The mungbean variety used was Vima 1 , and the maize variety was Bima. The results showed that intercropping mungbean with maize could increase the yield of mungbean seeds yield by $0,28 \mathrm{t} / \mathrm{ha}$ $(51,85 \%)$ and increase the mungbean biomass by $0,31 \mathrm{t} / \mathrm{ha}(22,30 \%)$ compared to the monoculture system. Different types and dosages of Phonska inorganic fertilizer and cow manure did not cause differences in the mungbean yield.

Keywords: dry land, intercropping, maize, mungbean, monoculture

\section{PENDAHULUAN}

Kacang hijau memiliki sifat toleran kekeringan dengan harga jual relatif tinggi dan stabil dibandingkan dengan tanaman aneka kacang lainnya (Radjit \& Prasetiaswati 2012). Palawija ini dapat dibudidayakan di lahan kering dan di lahan sawah irigasi pada musim kemarau setelah padi. Permintaan kacang hijau di Indonesia tergolong kontinu sepanjang tahun sehingga permintaan atas komoditas ini termasuk stabil dengan

Balai Penelitian Tanaman Aneka Kacang dan Umbi, JL. Raya Kendalpayak KM 8 Kotak Pos 66, Malang 65101

* Penulis Korespondensi:

Email: estawinasa@gmail.com harga jual yang cukup tinggi (Rahayu \& Srimayanti 2017). Cekaman kekeringan serta serangan hama thrips dan penyakit embun tepung merupakan konsekuensi jika menanam kacang hijau pada musim kemarau (Indiati 2012). Kacang hijau mempunyai karakteristik toleran kekeringan, berumur genjah, dan dapat ditanam pada daerah yang kurang subur, sehingga potensial untuk dikembangkan di lahan-lahan suboptimal (Trustinah et al. 2014).

Lahan suboptimal di wilayah Indonesia bagian timur pada umumnya adalah lahan kering beriklim kering (LKIK), dengan lahan yang cukup luas dan potensial untuk dikembangkan, tetapi belum dimanfaatkan secara intensif karena keterbatasan sumber daya air. Pengembangan pertanian di LKIK memiliki prospek 
yang sangat besar karena produksi dan produktivitas masih rendah dan dapat ditingkatkan melalui intensifikasi maupun ekstensifikasi (Mulyani et al. 2014). Adapun cara lain untuk memanfaatkan LKIK adalah melalui pancakelola LKIK yang dapat mendukung swasembada pangan melalui paket teknologi, yaitu (1) pengelolaan air; (2) pemupukan berimbang; (3) pengelolaan bahan organik, ameliorasi, dan konservasi tanah; (4) integrasi tanaman ternak; dan (5) penguatan kelembagaan tani (Heryani \& Rejekiningrum 2019).

Salah satu cara untuk memaksimumkan pemanfaatan dan produktivitas tanaman dan tanah di lahan kering adalah dengan menanam lebih dari satu jenis tanaman secara bersamaan. Sistem ini dikenal dengan istilah multiple cropping atau pola pertanaman ganda atau tumpang sari. Tumpang sari antara tanaman kacang hijau dan jagung dapat membentuk hubungan yang saling menguntungkan karena kacang hijau mampu memfiksasi $\mathrm{N}$ dari udara bebas yang dibutuhkan oleh tanaman jagung. Tanaman jagung yang lebih tinggi daripada kacang hijau dapat memberi naungan pada kacang hijau (Sabaruddin et al. 2011). Hasil kacang hijau dan jagung per satuan luas pada cara tanam monokultur lebih tinggi dibandingkan dengan cara tanam tumpang sari karena populasi tanaman pada cara tanam monokultur dua kali lebih banyak dibandingkan dengan cara tanam tumpang sari (Lingga et al. 2015).

Perbaikan teknologi budi daya berupa penggunaan varietas unggul dan benih berlabel, pengaturan jarak tanam, pemupukan, dan pengairan dua kali dapat meningkatkan produktivitas kacang hijau sampai 0,37 t/ha (47\%) (Rahayu \& Srimayanti 2017). Pemupukan $300 \mathrm{~kg}$ Phonska/ha dan 3 ton pupuk kandang/ha dapat meningkatkan hasil kacang hijau (Lestari \& Kuntyastuti 2016) dan residu dari pemupukan tersebut juga dapat meningkatkan hasil kacang tunggak (Lestari et al. 2018). Pemupukan $22,5 \mathrm{~kg} \mathrm{~N}+22.5 \mathrm{~kg} \mathrm{P} \mathrm{O}_{5}+22,5 \mathrm{~kg}$ $\mathrm{K}_{2} \mathrm{O}+15 \mathrm{~kg} \mathrm{~S} /$ ha dengan populasi 250.000 hingga 333.333 tanaman/ha dapat meningkatkan hasil kacang hijau pada LKIK (Kuntyastuti \& Lestari 2016). Penggunaan berbagai jenis pupuk (baik pupuk organik maupun pupuk anorganik) seperti pada beberapa pustaka yang telah disebutkan, merupakan salah satu komponen teknologi penting dalam budi daya tanaman dan dapat meningkatkan hasil yang cukup tinggi. Berkaitan dengan produktivitas LKIK, telah diteliti teknik budi daya berupa cara tanam dan pemupukan yang dapat meningkatkan hasil kacang hijau di Sumba Timur, NTT.

\section{METODE PENELITIAN}

Penelitian dilaksanakan di LKIK tipe iklim E (berdasarkan klasifikasi Oldeman) di Desa Laipori, Kecamatan Pandawai, Kabupaten Sumba Timur, NTT pada musim kemarau bulan Februari-Mei tahun 2017. Pada saat penelitian, pertanaman petani sudah dipanen, Biasanya petani menanam jagung atau kacang tanah pada awal musim hujan pada bulan November, dan hanya sekali tanam dalam setahun (IP, indeks pertanaman 100).

Benih jagung hibrida varietas Bima dan benih kacang hijau varietas Vima 1 ditanam pada petak berukuran $4 \mathrm{~m} \times 4 \mathrm{~m}$ menggunakan rancangan split plot dengan empat ulangan. Petak utama adalah cara tanam, yaitu (1) kacang hijau tumpang sari jagung dengan jarak tanam $30 \mathrm{~cm} \times 20 \mathrm{~cm}$, dua tanaman/lubang, dan jarak tanam jagung $(50 \mathrm{~cm} \times 50$ $\mathrm{cm}) \times 120 \mathrm{~cm}$, satu tanaman/lubang (10 baris kacang hijau, 2 baris ganda jagung), dan (2) kacang hijau monokultur dengan jarak tanam $40 \mathrm{~cm} \times 10 \mathrm{~cm}$, dua tanaman/lubang (10 baris kacang hijau). Anak petak adalah perlakuan pupuk organik dan pupuk anorganik, yaitu (1) $150 \mathrm{~kg}$ Phonska/ha, (2) $5000 \mathrm{~kg}$ pupuk kandang/ha, dan (3) 75 kg Phonska $+2500 \mathrm{~kg}$ pupuk kandang/ha.

Tanaman dipelihara secara intensif, bersih/terhindar baik dari gulma maupun serangan hama dan penyakit. Parameter yang diamati meliputi analisis kimia tanah sebelum tanam, intensitas radiasi matahari di bawah, di tengah dan di atas kanopi tanaman kacang hijau pada umur 20, 35, dan 45 HST (hari setelah tanam), bobot kering brangkasan dan tinggi tanaman pada umur 35 HST, serta hasil biji dan komponen hasil kacang hijau pada saat panen umur 55 HST. Analisis ragam diterapkan pada peubah pengamatan dan apabila berbeda nyata dilanjutkan dengan uji BNT pada taraf $5 \%$ dengan menggunakan program MstatC.

\section{HASIL DAN PEMBAHASAN}

Kabupaten Sumba Timur, NTT, merupakan salah satu wilayah yang lahannya tergolong LKIK dengan curah hujan kurang dari $2.000 \mathrm{~mm} /$ tahun; lahan bergelombang, berbukit, dan bergunung; tanah dangkal dan berbatu; serta ketersediaan air terbatas (Mulyani et al. 2014). Upaya meningkatkan pemanfaatan lahan di LKIK adalah melalui cara tanam tumpang sari. Selain meningkatkan produktivitas lahan, cara tanam ini juga dapat mengefisienkan waktu karena menanam dua jenis atau lebih tanaman dalam satu waktu yang bersamaan. Jagung yang ditumpangsarikan dengan kacang hijau dapat berdampak positif kerena terjadi sinergi mutualisme (Purnama et al. 2013).

\section{Kondisi Tanah}

Tanah LKIK di desa studi bereaksi agak alkalis, miskin unsur hara $\mathrm{N}$ dan $\mathrm{P}$. Tanah kaya akan bahan organik, unsur $\mathrm{K}$, $\mathrm{Ca}$, dan $\mathrm{Mg}$, sehingga tambahan pupuk diharapkan dapat mencukupi kebutuhan tanaman kacang hijau akan unsur hara, bukan hanya unsur K, Ca, dan Mg, tetapi juga unsur N dan P (Tabel 1). 
Tabel 1 Sifat kimia tanah sebelum tanam di lahan kering iklim kering (LKIK) Laipori, Nusa Tenggara Timur

\begin{tabular}{|c|c|c|}
\hline Sifat kimia & Laipori & Kriteria \\
\hline $\mathrm{pH} \mathrm{H} \mathrm{H}_{2} \mathrm{O}(1: 5)$ & 7,80 & Agak alkalis \\
\hline C-organik (\%) & 2,63 & Sedang \\
\hline N-Total (\%) & 0,10 & Rendah \\
\hline P-Bray 1 (ppm $\left.\mathrm{P}_{2} \mathrm{O}_{5}\right)$ & 8,78 & Rendah \\
\hline $\mathrm{K}-\mathrm{dd}(\mathrm{Cmol} / \mathrm{kg})$ & 1,10 & Sangat tinggi \\
\hline $\mathrm{Ca}(\mathrm{Cmol} / \mathrm{kg})$ & 42,00 & Sangat tinggi \\
\hline $\mathrm{Mg}(\mathrm{Cmol} / \mathrm{kg})$ & 7,34 & Tinggi \\
\hline $\mathrm{Fe}(\mathrm{Cmol} / \mathrm{kg})$ & nd & Tidak terdeteksi \\
\hline
\end{tabular}

Hasil analisis tanah sebelum tanam menunjukkan bahwa faktor pembatas produktivitas kacang hijau di LKIK Laipori adalah ketersediaan unsur $P$, yang diperparah oleh tingginya kadar kation basa $\mathrm{K}, \mathrm{Ca}$, dan Mg. Tingginya kadar ketiga unsur ini dapat menghambat ketersediaan dan serapan unsur $P$ sehingga memengaruhi hasil kacang hijau dan jagung. Ketersediaan air selama kurun waktu tiga bulan pertanaman di lapangan sangat minim, tidak ada hujan sama sekali, dan pengairan bergantung pada air dari sumur dengan sistem antrean. Tingkat ketersediaan air sangat berkaitan dengan proses penyerapan unsur hara oleh tanaman dalam proses metabolisme (Manan et al. 2015). Ketersediaan air di lapangan yang sangat minim mungkin memengaruhi ketersediaan hara dan menyebabkan hasil kacang hijau dan jagung tidak optimum. Hal tersebut sejalan dengan temuan Kadir (2011) pada tanaman padi yang mengemukakan bahwa cekaman kekeringan pada saat memasuki perkembangan tanaman dapat menurunkan hasil sampai $56,3 \%$.

\section{Intensitas Radiasi Matahari, Indeks Klorofil Daun, dan Pertumbuhan Kacang Hijau}

Pada pagi hari, intensitas radiasi surya yang sampai ke permukaan tanah di bawah kanopi tanaman kacang hijau umur 20 HST sekitar $60-70 \%$. Saat umur 35 HST, intensitas radiasi surya yang sampai di bawah kanopi tanaman kacang hijau menurun drastis, yaitu $<10 \%$. Pada cara tanam tumpang sari intensitas radiasi surya umur 45 HST menjadi $12 \%$ dan hanya $5 \%$ pada cara tanam monokultur. Hal ini disebabkan oleh tanaman kacang hijau tumbuh pesat pada umur $35 \mathrm{HST}$, mencapai fase pengisian dan pemasakan polong, dan perkembangan kanopi menghalangi penetrasi radiasi surya. Akibatnya intensitas radiasi surya yang sampai di permukaan tanah di bawah kanopi menurun. Pola yang sama juga terlihat pada pengamatan intensitas radiasi surya di bawah kanopi pada siang hari (Gambar 1).

Intensitas radiasi surya pada pagi hari pada saat tanaman kacang hijau berumur 20 HST pada tiga perlakuan pemupukan berkisar $60-75 \%$. Pada umur 35 HST, intensitas radiasi surya berkurang drastis, hanya 5-9\%. Intensitas radiasi surya di bawah kanopi tanaman kacang hijau umur 45 HST dengan perlakuan pupuk kandang dan kombinasi pupuk kandang dengan pupuk anorganik Phonska sedikit meningkat menjadi 10\%. Pada perlakuan pupuk anorganik Phonska, intensitas radiasi surya menurun menjadi hanya $4 \%$. Pada siang hari, intensitas radiasi surya di bawah kanopi tanaman kacang hijau umur 20 HST adalah 40-50\%. Intensitas radiasi surya di bawah kanopi kacang hijau semakin menurun menjadi $<10 \%$ dengan bertambahnya umur tanaman 45 HST (Gambar 2).

Penetrasi radiasi matahari sampai ke permukaan tanah berkaitan dengan produksi biomassa dan bentuk kanopi tanaman, apakah akan menghambat atau meneruskan radiasi sampai ke permukaan tanah baik di bawah maupun di antara kanopi. Nilai intensitas radiasi matahari di bawah kanopi pertanaman kacang hijau pada pagi maupun siang hari menurun seiring dengan bertambahnya umur tanaman. Berdasarkan penelitian Indrawan et al. (2017), hal tersebut disebabkan oleh kanopi tanaman yang semakin rapat sehingga penetrasi radiasi matahari berpenetrasi melalui tajuk tanaman menurun.

Contoh tanaman destruktif dikumpulkan pada saat tanaman kacang hijau berumur 45 HST dengan cara mencabut seluruh bagian tanaman. Perlakuan cara tanam memengaruhi indeks klorofil daun, sedangkan perlakuan pemupukan memengaruhi bobot kering akar. Bobot kering akar tanaman kacang hijau tertinggi diperoleh dengan pemberian $5000 \mathrm{~kg}$ pupuk kandang/ha (Tabel 2). Cara tanam monokultur menghasilkan indeks klorofil daun kacang hijau lebih tinggi dibandingkan dengan cara tanam tumpang sari. $\mathrm{Hal}$ ini dapat disebabkan oleh tanaman kacang hijau monokultur cukup menerima sinar matahari dan tidak ternaungi oleh kanopi tanaman jagung.

\section{Komponen Hasil dan Hasil Kacang Hijau}

Perlakuan cara tanam dan pemupukan tidak memengaruhi tinggi tanaman, jumlah cabang, jumlah polong isi, dan bobot biji/tanaman (Tabel 3). Interaksi antara cara tanam dan pemupukan hanya terjadi pada peubah jumlah polong isi/tanaman sedangkan pada peubah lain tidak terjadi interaksi. Hasil jumlah polong isi/tanaman tertinggi terdapat pada interaksi cara tanam tumpang sari dan pemupukan $5000 \mathrm{~kg}$ pupuk kandang/ha, walaupun pada interaksi cara tanam monokultur dan pemupukan $75 \mathrm{~kg}$ Phonska +2500 pupuk kandang/ha tidak berbeda nyata (Tabel 4). Hal ini mungkin disebabkan ada keterkaitan antara cara tanam dan aplikasi dosis dan jenis pupuk dengan jumlah polong isi.

Pemupukan tidak memengaruhi komponen hasil dan hasil biji kacang hijau. Sebaliknya, perbedaan cara 

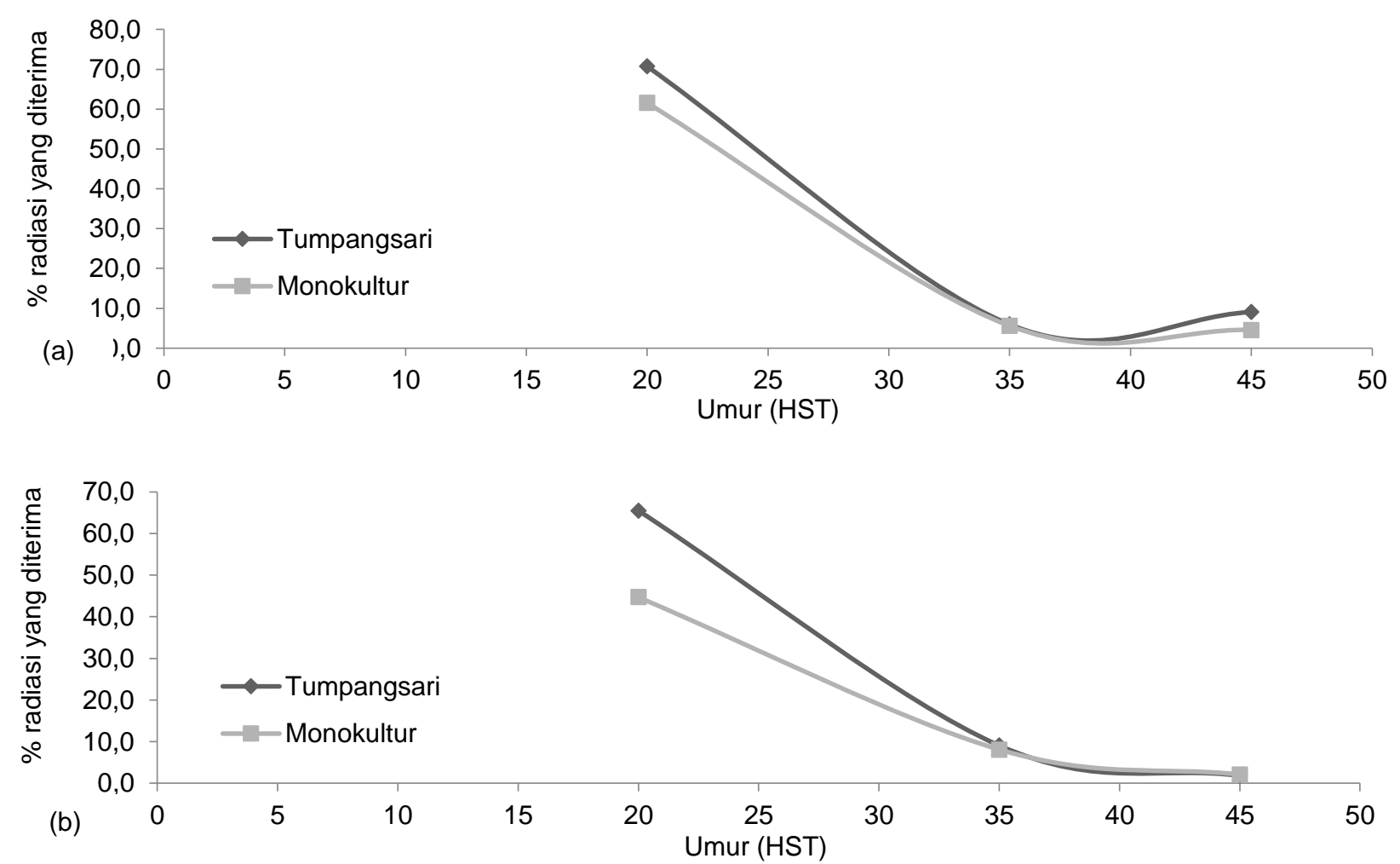

Gambar 1 Hubungan antara cara tanam dan intensitas radiasi surya di bawah kanopi pada pagi hari (a) dan siang hari (b) tanaman kacang hijau varietas Vima 1 di lahan kering iklim kering (LKIK) Laipori, Nusa Tenggara Timur.
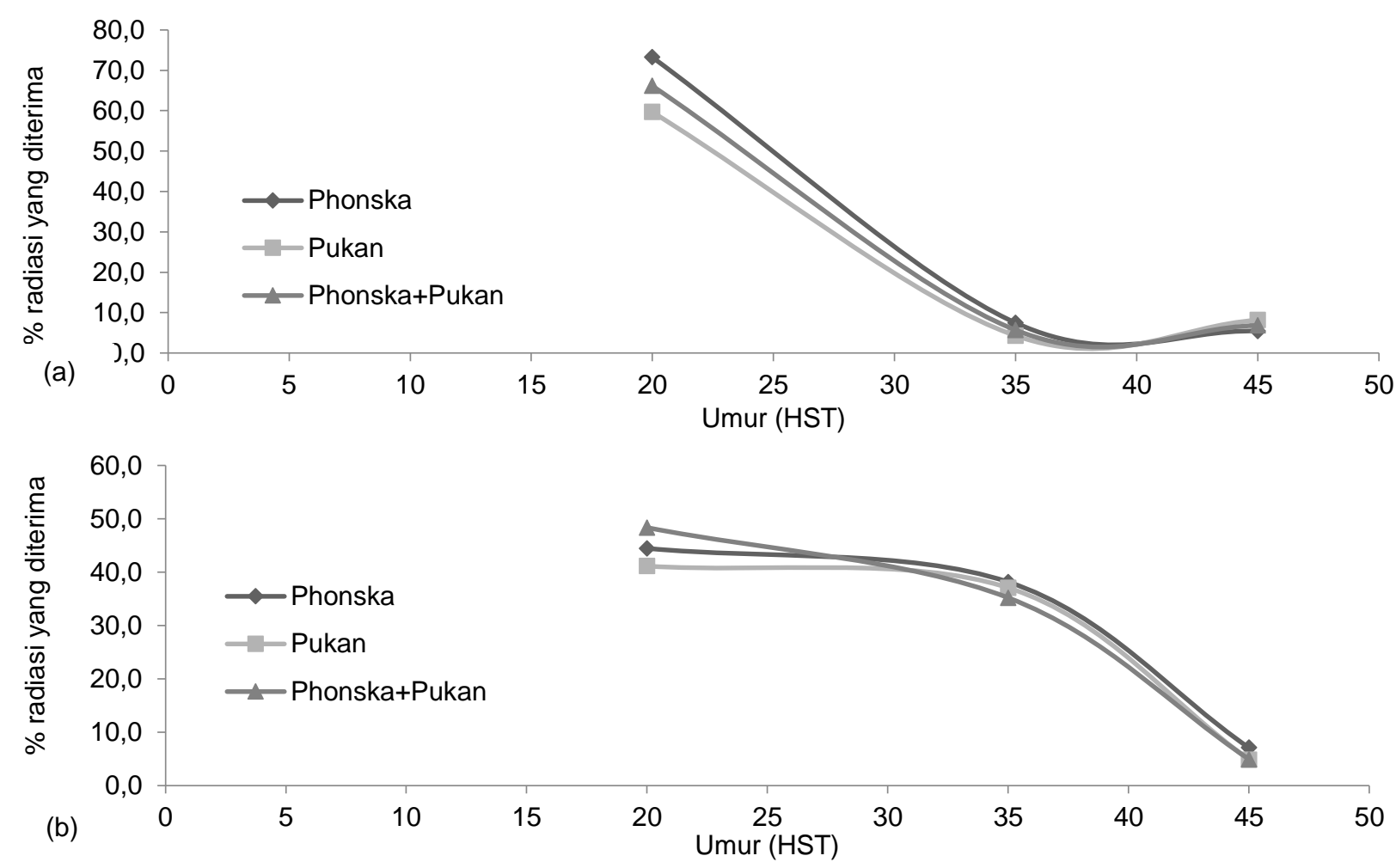

Gambar 2 Hubungan antara pengaruh pemupukan dan intensitas radiasi surya di bawah kanopi pada pagi hari (a) dan siang hari (b) tanaman kacang hijau varietas Vima 1 di lahan kering iklim kering (LKIK) Laipori, Nusa Tenggara Timur. 
Tabel 2 Pertumbuhan kacang hijau varietas Vima 1 umur 45 hari setelah tanam (HST) di lahan kering iklim kering (LKIK) Laipori, Nusa Tenggara Timur

\begin{tabular}{|c|c|c|c|c|}
\hline Perlakuan & $\begin{array}{c}\text { Tinggi tanaman } 45 \\
\text { HST }(\mathrm{cm})\end{array}$ & $\begin{array}{c}\text { Bobot kering } \\
\text { brangkasan ( } \mathrm{g} / \mathrm{tnm})\end{array}$ & $\begin{array}{c}\text { Bobot kering akar } \\
(\mathrm{g} / \mathrm{tnm})\end{array}$ & $\begin{array}{l}\text { Indeks klorofil } \\
\text { daun } 45 \text { HST }\end{array}$ \\
\hline \multicolumn{5}{|l|}{ Cara tanam } \\
\hline Tumpang sari & 33,9 a & $3,51^{\text {a }}$ & $0,43^{a}$ & $16,9^{b}$ \\
\hline Monokultur & $31,0^{\text {a }}$ & $4,25^{a}$ & $0,29^{\text {a }}$ & $30,7^{\text {a }}$ \\
\hline \multicolumn{5}{|l|}{ Pemupukan (kg/ha) } \\
\hline 150 Phonska & $30,7^{a}$ & $4,42^{a}$ & $0,34^{b}$ & $24,4^{a}$ \\
\hline 5000 pupuk kandang & $32,9^{a}$ & $3,97^{a}$ & $0,47^{a}$ & $23,7^{a}$ \\
\hline 75 Phonska +2500 pukan & $33,6^{a}$ & $3,25^{a}$ & $0,29 \mathrm{~b}$ & $23,2^{a}$ \\
\hline Interaksi & tn & tn & $\operatorname{tn}$ & tn \\
\hline $\mathrm{KK}(\%)$ & 12,61 & 11,44 & 18,35 & 13,05 \\
\hline
\end{tabular}

Keterangan: Angka di dalam kolom yang sama pada setiap faktor perlakuan yang diikuti oleh huruf yang sama berarti tidak berbeda nyata menurut uji BNT $5 \%$.

Tabel 3 Komponen hasil kacang hijau varietas Vima 1 di lahan kering iklim kering (LKIK) Laipori, Nusa Tenggara Timur

\begin{tabular}{|c|c|c|c|c|}
\hline Perlakuan & $\begin{array}{l}\text { Tinggi tanaman } \\
\text { panen }(\mathrm{cm})\end{array}$ & $\begin{array}{l}\text { Jumlah polong } \\
\text { isi/tanaman }\end{array}$ & $\begin{array}{c}\text { Jumlah } \\
\text { cabang/tanaman }\end{array}$ & $\begin{array}{c}\text { Bobot kering biji } \\
\text { (g/tanaman) }\end{array}$ \\
\hline \multicolumn{5}{|l|}{ Cara tanam (cm) } \\
\hline Tumpang sari & $38,1^{a}$ & $9,3^{\text {a }}$ & $1,2^{\mathrm{a}}$ & $3,3^{a}$ \\
\hline Monokultur & $36,4^{a}$ & $9,4^{\text {a }}$ & $1,4^{\mathrm{a}}$ & $3,6^{\mathrm{a}}$ \\
\hline \multicolumn{5}{|l|}{ Pemupukan (kg/ha) } \\
\hline 150 Phonska & $37,3^{a}$ & $8,4^{\text {a }}$ & $1,3^{a}$ & 3,3 a \\
\hline 5000 pupuk kandang & $37,8^{a}$ & $9,9^{\text {a }}$ & $1,1^{a}$ & $3,5^{\text {a }}$ \\
\hline 75 Phonska +2500 pukan & $36,6^{a}$ & $9,7^{a}$ & $1,4^{\mathrm{a}}$ & $3,5^{\text {a }}$ \\
\hline Interaksi & tn & * & tn & tn \\
\hline KK (\%) & 7,23 & 10,10 & 12,39 & 8,04 \\
\hline
\end{tabular}

Keterangan: Angka di dalam kolom yang sama pada setiap faktor perlakuan yang diikuti oleh huruf yang sama berarti tidak berbeda nyata menurut uji BNT 5\%.

Tabel 4 Pengaruh interaksi antara cara tanam dengan pemupukan terhadap jumlah polong isi tanaman kacang hijau

\begin{tabular}{lcccc}
\hline \multirow{2}{*}{ Cara tanam (cm) } & \multicolumn{4}{c}{ Pemupukan (kg/ha) } \\
\cline { 2 - 4 } & 150 Phonska & 5000 pupuk kandang & $\begin{array}{c}\text { 75 Phonska }+2500 \text { pupuk } \\
\text { kandang }\end{array}$ & Rata-rata \\
\hline Tumpang sari & $8,3^{\mathrm{b}}$ & $11,6^{\mathrm{a}}$ & $8,1^{\mathrm{b}}$ & 9,3 \\
Monokultur & $8,6^{\mathrm{b}}$ & $8,2^{\mathrm{b}}$ & $11,4^{\mathrm{a}}$ & 9,4 \\
\hline Rata-rata & 8,45 & 9,9 & 9,75 &
\end{tabular}

Keterangan: Angka di dalam kolom yang sama pada setiap faktor perlakuan yang diikuti oleh huruf yang sama berarti tidak berbeda nyata menurut uji BNT 5\%.

tanam monokultur dan tumpang sari memengaruhi jumlah tanaman saat panen, bobot kering polong, hasil biji, dan biomassa panen kacang hijau. Populasi tanaman kacang hijau saat panen pada cara tanam monokultur lebih tinggi dibandingkan dengan cara tanam tumpang sari. Bobot kering polong, hasil biji, dan produksi biomassa panen kacang hijau pada pertanaman tumpang sari dengan jagung lebih tinggi daripada pertanaman monokultur dengan persentase berturut-turut 53,25\%, 51,85\%, dan 22,30\% (Tabel 5). Lebih tingginya hasil biji dan produksi biomassa kacang hijau pada pertanaman tumpang sari ternyata ditunjang oleh lebih tingginya kadar unsur hara $\mathrm{N}, \mathrm{K}$, dan $\mathrm{Mg}$ dalam biji kacang hijau pada pertanaman tumpang sari daripada pertanaman monokultur (Tabel 6). Sistem tumpang sari akan berdampak pada ketersediaan unsur hara jika dibandingkan dengan sistem monokultur, unsur hara tersebut digunakan untuk pertumbuhan dan perkembangan tanaman sehingga dapat meningkatkan hasil tanaman (Yuliani et al. 2017).

Pada penelitian ini, nilai nisbah kesetaraan lahan (NKL) antara tanaman monokultur dan tumpang sari ialah 1,52. Tumpang sari jagung dengan kacang hijau memiliki NKL > 1, berarti bahwa cara ini efisien secara ekologi dan agronomi (Lestari et al. 2019), sedangkan jika NKL < 1, berarti tidak menguntungkan untuk pertanaman tumpang sari (Yuwariah 2011).

\section{KESIMPULAN}

Cara tanam tumpang sari kacang hijau dengan jagung dapat meningkatkan hasil kacang hijau sebesar $0,28 \mathrm{t} / \mathrm{ha}(51,85 \%)$ dan meningkatkan biomassa panen kacang hijau sebesar 0,31 t/ha (22,30\%) dibandingkan dengan cara tanam monokultur. Perbedaan jenis dan takaran pupuk anorganik Phonska dan pupuk kandang tidak menyebabkan perbedaan hasil kacang hijau. 
Tabel 5 Hasil biji dan biomas panen kacang hijau varietas Vima 1 di lahan kering iklim kering (LKIK) Laipori, Nusa Tenggara Timur

\begin{tabular}{|c|c|c|c|c|}
\hline Perlakuan & $\begin{array}{c}\text { Jumlah } \\
\text { tanaman/ha }\end{array}$ & Bobot kering polong (t/ha) & Hasil biji (t/ha) & Bobot biomas (t/ha) \\
\hline \multicolumn{5}{|l|}{ Cara tanam $(\mathrm{cm})$} \\
\hline Tumpang sari & $263.174 \mathrm{~b}$ & $1,18 \mathrm{a}$ & $0,82 \mathrm{a}$ & $1,70 \mathrm{a}$ \\
\hline Monokultur & $354.362 \mathrm{a}$ & $0,77 \mathrm{~b}$ & $0,54 \mathrm{~b}$ & $1,39 \mathrm{~b}$ \\
\hline \multicolumn{5}{|l|}{ Pemupukan (kg/ha) } \\
\hline 150 Phonska & $303.745 \mathrm{a}$ & $0,91 \mathrm{a}$ & $0,64 \mathrm{a}$ & $1,49 a$ \\
\hline 5000 pupuk kandang & $310.202 \mathrm{a}$ & $1,02 \mathrm{a}$ & $0,71 \mathrm{a}$ & $1,53 \mathrm{a}$ \\
\hline 75 Phonska +2500 pukan & $312.356 \mathrm{a}$ & $0,99 \mathrm{a}$ & $0,69 \mathrm{a}$ & $1,61 \mathrm{a}$ \\
\hline Interaksi & tn & tn & tn & tn \\
\hline $\mathrm{KK}(\%)$ & 9,94 & 6,65 & 4,80 & 7,76 \\
\hline
\end{tabular}

Keterangan: Angka di dalam kolom yang sama pada setiap faktor perlakuan yang diikuti oleh huruf yang sama berarti tidak berbeda nyata menurut uji BNT 5\%.

Tabel 6 Kadar hara dalam biji kacang hijau varietas Vima 1 di lahan kering iklim kering (LKIK) Laipori, Nusa Tenggara Timur

\begin{tabular}{|c|c|c|c|c|c|c|}
\hline \multirow{2}{*}{ Perlakuan } & \multicolumn{6}{|c|}{ Kadar hara dalam biji kacang hijau (\%) } \\
\hline & $\mathrm{N}$ & $\mathrm{P}$ & $\mathrm{K}$ & $\mathrm{Ca}$ & $\mathrm{Mg}$ & $\mathrm{S}$ \\
\hline \multicolumn{7}{|l|}{ Cara tanam $(\mathrm{cm})$} \\
\hline Tumpang sari & 3,61 & 0,15 & 4,19 & 0,40 & 0,15 & 0,09 \\
\hline Monokultur & 3,47 & 0,14 & 3,30 & 0,38 & 0,11 & 0,07 \\
\hline \multicolumn{7}{|l|}{ Pemupukan (kg/ha) } \\
\hline 150 Phonska & 3,58 & 0,16 & 3,74 & 0,40 & 0,15 & 0,10 \\
\hline 5000 pupuk kandang & 3,73 & 0,14 & 3,58 & 0,39 & 0,12 & 0,08 \\
\hline 75 Phonska +2500 pukan & 3,32 & 0,15 & 3,92 & 0,39 & 0,13 & 0,08 \\
\hline Rata-rata & 3,54 & 0,15 & 3,75 & 0,39 & 0,13 & 0,08 \\
\hline
\end{tabular}

\section{DAFTAR PUSTAKA}

Heryani N, Rejekiningrum P. 2019. Pengembangan pertanian lahan kering iklim kering melalui implementasi panca kelola lahan. Jurnal Sumberdaya Lahan. 13(2): 63-71.

Indiati SW. 2014. Pengaruh insektisida nabati terhadap hama thrips dan hasil kacang hijau. Jurnal Pertanian Tanaman Pangan. 31(3): 152-157.

Indrawan RR, Suryanto A, Soelistyono R. 2017. Kajian iklim mikro terhadap berbagai sistem tanam dan populasi tanaman jagung manis (Zea mays saccharata Sturt.). Jurnal Produksi Pertanian. 5(1): 92-99.

Kadir A. 2011. Respon genotipe padi mutan hasil radiasi sinar gamma terhadap cekaman kekeringan. Jurnal Agrivigor. 10(3): 235-246.

Kuntyastuti H, Lestari SAD. 2016. Pengaruh interaksi antara dosis pupuk dan populasi tanaman terhadap pertumbuhan dan hasil kacang hijau pada lahan kering beriklim kering. Penelitian Pertanian Tanaman Pangan. 35(3): 239-250.

Lestari SAD, Kuntyastuti H. 2016. Pengaruh pupuk kandang dan pupuk anorganik terhadap berbagai varietas kacang hijau di tanah masam. Buletin Palawija. 14(2): 55-62.

Lestari SAD, Sutrisno, Kuntyastuti H. 2018. Pengaruh pupuk terhadap pertanaman kacang hijau dan residunya pada tanaman kacang tunggak. Jurnal
IImu Pertanian Indonesia 23(1): 21-28. https://doi.org/10.18343/jipi.23.1.21

Lestari D, Turmudi E, Suryati D. 2019. Efisiensi pemanfaatan lahan pada sistem tumpang sari dengan berbagai jarak tanam jagung dan varietas kacang hijau. Jurnal IImu-IImu Pertanian Indonesia 21(2): 82-90. https://doi.org.10.31186/jipi/21.2.8290

Lingga GK, Purwanti S, Toekidjo. 2015. Hasil dan kualitas benih kacang hijau (Vigna radiata (L.) Wilczek) tumpang sari barisan dengan jagung manis (Zea mays Saccharata). Jurnal Vegetalika. 4(2): 39-47.

Manan AA, Machfudz WDP. 2015. Pengaruh volume air dan pola vertikultur terhadap pertumbuhan dan hasil sawi hijau (Brassica juncea L.). Journal of Universitas Muhammadiyah Sidoarjo. 12(1): 33-43.

Mulyani A, Nursyamsi D, Las I. 2014. Percepatan pengembangan pertanian lahan kering iklim kering di Nusa Tenggara. Pengembangan Inovasi Pertanian. 7(4): 187-198.

Purnama JM, Tohari, Kastono D. 2013. Kajian teknologi parit berbahan organik pada produktivitas tumpang sari jagung (Zea mays L.) dengan kacang hijau (Vigna radiata [L.] Wilczek) di lahan kering. Vegetalika. 2(2): 40-49.

Radjit BS, Prasetiaswati N. 2012. Prospek kacang hijau pada musim kemarau di Jawa Tengah. Buletin Palawija. 24: 57-68. 
Rahayu SP, Srimayanti TS. 2017. Perbaikan teknologi budi daya kacang hijau dan analisis usaha tani di Kabupaten Ponorogo, Jawa Timur. Prosiding Seminar Nasional Masyarakat Biodiversitas Indonesia 3(2): 183-188. https:// doi.org/10.13057/ psnmbi/m030203

Sabaruddin L, Hasid R, Muhidin, Anas AA. 2011. Pertumbuhan, produksi, dan efisiensi pemanfaatan lahan dalam sistem tumpang sari jagung dan kacang hijau dengan interval penyiraman berbeda. Jurnal Agronomi Indonesia. 39(3): 153-159.
Trustinah, Radjit BS, Prasetiaswati N, Harnowo D. 2014. Adopsi varietas unggul kacang hijau di sentra produksi. Iptek Tanaman Pangan. 9(1): 24-38.

Yuliani N, Sumarni T, Sebayang HT. 2017. Pengaruh tanaman sela pada pertumbuhan dan hasil tanaman jagung (Zea mays L.) dengan tiga taraf dosis nitrogen. Jurnal Produksi Tanaman. 5(12): 1979-1987.

Yuwariah Y. 2011. Peran Tanam Sela dan Tumpang sari Bersisipan Berbasis Padi Gogo Toleran Naungan. Bandung (ID): Giratuna. 